\title{
編集後記
}

このたびTHE KITAKANTO MEDICAL JOURNAL は表紙を一新することになりました. 現 在の雑誌の表紙の色が日本工業規格 (JIS 規格) の色見本に基づく色ではなく, 雑誌印刷ごとに印 刷業者が長年の経験により，以前に発刊された雑誌に似た色を配色・印刷してきたという経緯が あり，それを是正するために色見本に準拠した色を採用した表紙に改訂することになりました。 デザイン会社から 2 種類の表紙案が提出され，編集委員会で検討した結果，このたび採用される デザインになりました.

現在のデザインは上毛三山をモチーフにしたシンプルなものですが，新たなデザインは一流科 学雑誌の表紙に類似しています. 新たな表紙の雑誌を手にした読者はそれが THE KITAKANTO MEDICAL JOURNAL であることを認識できないか，ダイレクトメールで送られてきた雑誌の 見本と見間違うことと思います.

また，今年の北関東医学会総会では一般演題のインターネットによる演題登録が試験的に行わ れました. 学会事務局に負担となりますが, 来年度の総会からインターネットによる演題登録の みにする準備も始まっています。インターネットによる演題登録が一般的である現状を考慮しま すと, 紙媒体を用いて行う, 従来型の演題登録は若い研究者には奇異に映っていたかもしれませ ん.

THE KITAKANTO MEDICAL JOURNAL は医学雑誌であり, 科学雑誌ですので, 科学の進歩 に合わせた雑誌作りが求められています. 投稿, 查読, 校正等の論文出版過程全てがオンライン化 されるときは近いと思います.また, 日本の科学政策が一層推進・増強され, 科学雑誌出版への補 助金獲得が容易になれば, THE KITAKANTO MEDICAL JOURNAL をオンラインジャーナル 化し, 全世界へ向けて情報を発信し, インパクトファクターを獲得する日がくるかもしれません。

(小湊慶彦 記)

\section{THE KITAKANTO MEDICAL JOURNAL}

\section{北関 東 医 学}

編集委員 (Editors)

委 員 長 (Editor-in-Chief)

石崎泰樹 Yasuki ISHIZAKI, M.D., Ph.D.

委

員 (Associate Editors)

対馬義人 Yoshito TSUSHIMA, M.D., Ph.D

小湊慶彦 Yoshihiko KOMINATO, M.D., Ph.D.

横尾英明 Hideaki YOKOO, M.D., Ph.D.

伊藤一人 Kazuto ITO, M.D., Ph.D.

海外委員 (Oversea Editors)

M.Nurhalim SHAHIB, M.D., Ph.D.

(Univ.Padjadjaran)

牛久保美津子 Mitsuko USHIKUBO, RN, MA, Ph.D. 常盤洋子 Yoko TOKIWA, RN, PHN, NM, Ph.D. 高橋昭久 Akihisa TAKAHASHI, Ph.D. 柴崎貢志 Koji SHIBASAKI, Ph.D.

Dedi SUBARDJA, M.D., Ph.D.

(Univ.Padjadjaran) 
